\title{
Could "degrowth" have the same fate as "sustainable development"? A discussion on passive revolution in the Anthropocene age
}

\author{
Nikos Trantas ${ }^{1}$ \\ Independent Scholar, Greece
}

\begin{abstract}
The sustainable development discourse, including the modern green growth version, may have aspects that contribute to environmental and social welfare but it is a top down reform project, that aims at correcting the environmental and social externalities resulting from economic growth. It is directed by governments that abide by the logic of capital. Although in principle there is civic engagement, public participation is limited and without challenging the dominant economic paradigm. Following Gramsci's terminology, sustainable development can be interpreted as a passive revolution, in the sense that change is managed through compromises with different social and political actors but within limits which neutralize any potential threat to economic and political power. On the contrary, the emerging (yet still marginal) alternative, multi-disciplinary, degrowth academic paradigm, has evolved from an activist movement since the first decade of this century, and retains close contacts and open communication with social movements that support a degrowth transition in economy and society. This transition directly challenges the established orthodox growth narrative and the mechanisms of capital accumulation. Thus, in contrast to the sustainable development discourse, it is difficult for the "power bloc" to accommodate degrowth. But in times of crisis and change, the dominant powers can certainly use some aspects of the degrowth discourse, assimilating and transforming them into elements that fit their new accumulation strategies, hegemonic visions and state projects. For this not to happen, degrowthers should focus their research and theory more on the workings of capitalist political economy, and their political practice on trying to form alliances with social actors, such as working-class movements, that are crucial for the achievement of hegemony.
\end{abstract}

Key words: degrowth, sustainable development, green growth, European Green Deal, passive revolution, Gramsci, capitalism, eco-socialism

\section{Résumé}

Le discours sur le développement durable, y compris la version moderne de la croissance verte, peut avoir des aspects qui contribuent au bien-être environnemental et social, mais il s'agit essentiellement d'un projet de réforme descendante qui vise à corriger les externalités environnementales et sociales de la croissance économique. Il est géré par des gouvernements qui respectent la logique du capital et, bien qu'en principe il favorise l'engagement civique, la participation du public est limitée et se fait d'une manière qui ne remet pas sérieusement en question le paradigme économique dominant. Selon la terminologie de Gramsci, il peut être interprété comme un cas de révolution passive, en ce sens que le changement est géré par des compromis avec différents acteurs sociaux et politiques, mais dans des limites qui neutralisent toute menace potentielle pour le pouvoir économique et politique. Au contraire, l'émergent (mais encore marginal) paradigme académique alternatif et multidisciplinaire de décroissance, a évolué, de manière cohérente et assez influente depuis la première décennie de ce siècle, à partir d'un mouvement activiste. Il conserve des contacts étroits et une communication ouverte avec des mouvements sociaux qui soutiennent une transition vers la décroissance de l'économie et de la société. Cette transition remet directement en question le discours orthodoxe sur la croissance, et les mécanismes d'accumulation du capital. Ainsi, contrairement au discours du développement durable, il est difficile pour le «bloc au pouvoir» de s'accommoder du discours de la décroissance. Mais en temps de crise et de changement, les puissances dominantes peuvent certainement utiliser certains aspects du

\footnotetext{
${ }^{1}$ Dr. Nikos Trantas, independent scholar, political scientist and civil servant in the Presidency of the Government, Athens, Greece. Email: nick.trantas "at" gmail.com. Acknowledgements: I thank Prof. Giorgos Kallis, and the editors and reviewers of the JPE for their comments and assistance.
} 
discours sur la décroissance, les assimiler et les transformer en éléments qui peuvent s'intégrer dans leurs stratégies d'accumulation renommées, leurs visions hégémoniques et leurs projets étatiques. Pour que cela ne se produise pas, les décroissants devraient concentrer davantage leurs recherches et leur théorie sur le fonctionnement de l'économie politique capitaliste, et leur pratique politique en essayant de former des alliances avec des acteurs sociaux, tels que les mouvements de la classe ouvrière, qui sont cruciaux pour la réalisation de l'hégémonie.

Mots clés: décroissance, développement durable, croissance verte, pacte vert pour l'Europe, révolution passive, Gramsci, capitalisme, eco-socialisme

\section{Resumen}

El discurso del desarrollo sostenible, incluida la versión moderna del crecimiento verde, puede tener aspectos que contribuyan al bienestar ambiental y social, pero es básicamente un proyecto de reforma descendente que tiene como objetivo corregir las externalidades ambientales y sociales del crecimiento económico. Está dirigido por gobiernos que se rigen por la lógica del capital y, aunque en principio promueve el compromiso cívico, la participación pública es limitada y se realiza de una manera que no desafía seriamente el paradigma económico dominante. Siguiendo la terminología de Gramsci, se puede interpretar como un caso de revolución pasiva, en el sentido de que el cambio se gestiona a través de compromisos con diferentes actores sociales y políticos pero dentro de límites que neutralizan cualquier amenaza potencial al poder económico y político. Por el contrario, el emergente (aunque aún marginal) paradigma académico alternativo y multidisciplinario de decrecimiento, ha evolucionado, de manera consistente y bastante influyente desde la primera década de este siglo, a partir de un movimiento activista y conserva contactos estrechos y una comunicación abierta con movimientos sociales que apoyan una transición hacia el decrecimiento en la economía y la sociedad. Esta transición desafía directamente la narrativa de crecimiento ortodoxa establecida y los mecanismos de acumulación de capital. Por lo tanto, en contraste con el discurso del desarrollo sostenible, es difícil para el "bloque de poder" adaptarse al discurso del decrecimiento. Pero en tiempos de crisis y cambio los poderes dominantes ciertamente pueden utilizar algunos aspectos del discurso del decrecimiento, asimilarlos y transformarlos en elementos que puedan encajar en sus reconocidas estrategias de acumulación, visiones hegemónicas y proyectos estatales. Para que esto no suceda, los decrecientes deben enfocar su investigación y teoría más en el funcionamiento de la economía política capitalista y su práctica política en tratar de formar alianzas con actores sociales, como los movimientos de la clase trabajadora, que son cruciales para el logro de la hegemonía.

Palabras clave: Decrecimiento, desarrollo sostenible, crecimiento verde, pacto verde Europeo, revolución pasiva, Gramsci, capitalismo, eco-socialismo

\section{Introduction}

In the Journal of Political Ecology's (JPE) Special Section on degrowth, Susan Paulson's introduction (2017) refers to the paradox of having a lot of information and not enough change: "harmful environmental consequences of growth have been rigorously documented and widely publicized throughout the past halfcentury. Yet, the quantity of matter and energy used by human economies continues to increase by the minute, while governments and businesses continue to promise and to prioritize further economic growth." She then offers her theoretical approach to change, by drawing attention to systems of culture and power, and finding potential for transformative change in habitual practices and in cultural systems that govern these practices and make them meaningful. The sixteen case studies presented in the JPE's Special Section on degrowth illustrate how diverse communities around the world are able to prioritize wellbeing, equity and sustainability rather than expansion, contributing in this way to a decolonization of worldviews of expansionist myths and values.

This article serves as a contribution to explaining the above paradox. I will first discuss the official, mainstream policy contexts of sustainable development and green growth, supporting the view that the reason for their failure can be traced to the false premises that they lie in, as they struggle to mitigate environmental and social problems while at the same time keeping the (capitalist) economic growth machine running at full speed. I will then schematically present the ascendant "degrowth" paradigm, which is critical of mainstream policies and attempts to offer alternative solutions to the sustainability case. In contrast to the discourse of sustainable development and, even more so, of 'green growth', degrowth's critique of the affluent consumer 
society challenges some basic tenets of capitalism and makes it difficult for the dominant powers to accommodate it the same way they have done with the original case of sustainable development. A degrowth transition in economy and society, if implemented, will have serious consequences for the way things are now operating, but one must not forget or underestimate the assimilating capabilities of "bourgeois" forces. After all, both sustainable development and degrowth are heavily contested concepts, "empty/floating signifiers", which various social groups and institutions, with unequal power relations, are constantly struggling to give meaning to (Laclau 1977; Laclau and Mouffe 1985).

I use concepts from the Gramscian political science tradition to discuss if degrowth has the potential to successfully deconstruct the growth imaginary not only in academic circles but in the political terrain as well, and if parts of its agenda could be introduced to the official policymaking processes in an integral or co-opted way.

\section{Passive revolution}

Going back from the Age of Anthropocene to an Italian prison in the 1930 s, $^{2}$ we would find Antonio Gramsci writing his notes on interpreting the $19^{\text {th }}$ century Risorgimento (movement for the Italian unification) and other phenomena of European history, as an outcome of "passive revolution", a strategy of the bourgeoisie in the "war of position", exercised in times of weak hegemony. ${ }^{3}$ It was a revolution, because it involved a reorganization of social relations, but passive, in the sense that popular participation was contained, popular interests were not organically integrated in the hegemonic "national-popular" project, and political leadership did not alter in a substantial way (Jessop 1983: 105). ${ }^{4}$ Passive revolution then is about trying "to manage change and maintain control of economic and political power through compromises with different social interests and political forces within limits which neutralise anything which presents a serious threat" (Sassoon 2000: 18). In a passive revolution, the interests of the dominant forces are imposed on the popular masses "through a war of position which advances particular popular interests (if at all) through a mechanical game of compromise rather than their organic integration into a 'national-popular' project" (Jessop 1983: 105). This differs from an expansive hegemony, as the latter requires the active support of the people to a hegemonic vision (and state project $)^{5}$, on the basis of symbolic and material rewards that the popular masses receive in a national-popular program, which aims to advance not only the immediate "corporate" interests of the dominant group, but a very broad coalition of forces, ideally the whole nation. This is a basic precondition for forming a "historical bloc", which is about the "unity between structure and superstructure" and the formation of a homogeneous politicoeconomic alliance, without internal contradictions (Gramsci 1971: 137, 366, 168). Topographically, therefore, passive revolution covers the space of the "war of position" between an expansive hegemony and an open "war of maneuver" (or "war of movement") against the popular masses, and it includes not only normal reformist

\footnotetext{
${ }^{2}$ The 1930s could be also considered part of the Anthropocene, but I use a rather narrow definition here, by referring to the post mid-twentieth century era, where human activity exercises a dominant influence on climate change and the environment. For issues concerning the official adoption of the Anthropocene geological epoch by the International Geological Congress, the starting date of the new era, or the preferable use of alternative terms, such as Capitalocene, see among others Crutzen and Stoermer 2000; Davies and Todd 2017; Moore 2016; Haraway 2015 and Davies 2018.

3 "The 'passive' aspect of the great revolution which started in France in 1789 and which spilled over into the rest of Europe with the republican and Napoleonic armies - giving the old regimes a powerful shove, and resulting not in their immediate collapse as in France but in the 'reformist' corrosion of them which lasted up to 1870 ...the demands which in France found a Jacobin-Napoleonic expression were satisfied in small doses, legally, in a reformist manner - in such a way that it was possible to preserve the political and economic position of the old feudal classes, to avoid agrarian reform, and, especially, to avoid the popular masses going through a period of political experience such as occurred in France in the years of Jacobinism." (Sassoon 1987: 205; Gramsci 1971: 119)

${ }^{4}$ However, the fact that a class, like the old feudal classes, manages to maintain its political role does not necessarily mean that it keeps being economically and politically dominant. It could have become just a governing group in the meantime serving the dominance of another class, the bourgeoisie (Sassoon 1987: 206; Gramsci 1971: 115).

${ }^{5}$ Jessop in his earlier work used to refer to "hegemonic projects", but he now calls them "hegemonic visions." As the state is just one part of a complex social order, "the 'state project' corresponds to the 'part' moment of the 'part-whole' paradox of the state", whereas the "'hegemonic vision' reflects its 'whole' moment", and offers "general guidelines for conducting state policy" (Jessop 2016: 86).
} 
forms of social control but also goes all the way to the use of "force, fraud, and corruption", where it borders with the war of maneuver. Gramsci viewed the 1930s reorganization of capitalism, involving the increased state intervention in the economy and society that took a variety of political forms, such as the New Deal in USA and Fascism in Italy, as cases of passive revolution (Sassoon 1987: 208; Gramsci 1971: 119).

I argue that sustainable development, as expressed at the international level in the current 2030 Agenda of the Sustainable Development Goals (SDGs) (UN General Assembly Resolution 2015), and in other regional and national contexts, can be interpreted, mutatis mutandis, as a passive revolution case, in the sense that the dominant social classes and groups are pursuing their hegemonic visions, state projects and accumulation strategies by assimilating certain demands from the subaltern and opposing social and political forces and transforming their radical potential into politically harmless elements. In this way, they succeed in 'decapitating' the revolutionary/emancipatory potential of their adversary (the emerging "collective will") and secure their own dominance or, even better, hegemony. This process takes place in civil society and the ("integral") state, through two modes of hegemonic articulation, as introduced by Laclau and Mouffe's critical discourse theory (1977, 1985). The discourse of difference, whereas the ideological antagonistic elements are neutralized and reinterpreted as mere complementary differences within a national-popular collective will (historical examples include Giolliti's Transformismo and Disraeli's "One Nation"), and the discourse of equivalence, where a system of equivalences is formed among different elements, which leads to the formation of an antagonistic pole standing in juxtaposition to the opposite pole of an irreducible antagonistic polarity, in a friend or foe pattern of distinction (examples include Jacobinism, Fascism, Maoism) (Laclau 2005, 2006; Jessop 2019).

These contingent political-discursive practices, however, are taking place in path-dependent social formations with long-established institutions, not-so-discursive structures (if I may call them that way for reasons of emphasis) or "sedimented practices" (as Laclau calls them, i.e. discursive articulations that have been selected and stabilized but can be contested politically later), and particular forms of articulation of the political with other ontologically distinct fields, such as the economy and ecology. ${ }^{6}$

This means that the "laws of motion" of capitalism set some very definite limits on the applicability of policy proposals made by the degrowth school of thought, thus untangling the paradox of too much information and not enough change that Paulson (2017) is referring to. For this reason, degrowth is considered radical or utopian, while the "ecomodernists" of sustainable development and green growth, who are not threatening the operating mode of capitalism, are dominating the green political economy discourse.

But as Régulation theory (Boyer and Saillard 2002) has shown, there is a variety of accumulation regimes and modes of regulation that can secure for a certain historical period the reproduction of capitalist social formations. So, in the event the mainstream policies will continue to fail and environmental, economic and social problems mount up, leading the various modes of growth to crisis, nothing precludes the possibility for the dominant powers to adopt some degrowth measures in a passive revolution manner, by transforming them not only into harmless elements in their hegemonic visions but also beneficial features of their immediate economic interests in new concrete state projects.

\section{The problem with sustainable development}

Given the heavy legacy of the industrial revolution and the overwhelming hegemony of the growth paradigm at the second half of 20th century (Schmelzer 2016), we should not underestimate the emergence of "human development" and, in parallel, "sustainable development" discourses, both to a large extent within the United Nations framework. The human development discourse, influenced by the "capability approach" (Nussbaum 2011; Sen 1999), criticized the one-dimensional quantitative glorification of economic growth, defined as growth in Growth Domestic Product (GDP), and introduced important qualitative parameters. Since at least 1990, where the first Human Development Report was published (UNDP 1990), development has been seen not in a strict economic growth sense, but as a process geared to creating an environment for people,

6. See Jessop's (2019) assessment of critical discourse theory and his third way approach of a Cultural Political Economy (Sum and Jessop 2013) that aims to avoid the "Constructivist Charybdis" and the "Structuralist Scylla", by seeking to explain why some discursive articulations get selected (instead of others) and become sedimented, and why some properties of institutions have enduring effects at different scales of action. 
individually and collectively, to develop their full potential and to have a reasonable chance of leading productive and creative lives that they value. This is measured by the Human Development Index and other relevant indexes, indicators and disaggregated data that are used either in the United Nations framework or beyond. The problem of rising inequalities within and among countries is highlighted (UNDESA 2020), and according to the 2019 Human Development Report (UNDP 2019: 6-9), a new generation of inequalities is emerging that concern the "enhanced capabilities" of humans (access to quality health at all levels, high-quality education at all levels, effective access to present-day technologies, resilience to unknown new shocks), that deepen the divergence between countries, even if a convergence is taking place in the "basic capabilities" tier, which have to do with conditions of extreme deprivation (early childhood survival, primary education, entrylevel technology, resilience to recurrent shocks).

If social issues were the main focus of the human development approach, the environmental dimension, and its relation to major social problems such as poverty, was the motivating force of the sustainable development approach. The standard WCED (1987) definition of sustainable development as "development that meets the needs of the present without compromising the ability of the future generations to meet their own needs", may be somewhat vague on what it means to "meet the needs", but quite clear on the need for some kind of ecological sustainability and intergenerational justice. How can this be achieved is described in the UN's declarations, policy proposals and action plans, and at a national level in the voluntary national review reports that the states are presenting in the UN High-level Political Forum on Sustainable Development, as part of the reviewing mechanism of the SDGs implementation process. And it all pretty much comes down to Brundtland's foreword to the 1987 Our Common Future report: "These links between poverty, inequality and environmental degradation formed a major theme in our analysis and recommendations. What is needed now is a new era of economic growth - growth that is forceful and at the same time socially and environmentally sustainable" (WCED 1987).

Well, as the degrowth, postgrowth or 'steady-state economy' schools of thought would argue, this is the problem with sustainable development; the primacy of economic growth considerations and the positivist/modernist belief that in the three-circle intersection of economic growth, with environmental protection and social justice, "win-win" policies can be implemented. Sustainable development has been called an "oxymoron", an attempt to square the circle, to have one's cake and eat it too, for "how can we protect nature while keeping on competing and growing economically?" (Sachs 1999: 71, xii). Many reviews of the concept (Dobson 1999; Jacobs 1999; Lélé 1991; Springett and Redclift 2015; Reid 1995) acknowledge the dominance of growth-oriented policies and their contradictory position to sustainability priorities, and also comment on the vagueness and ambiguity of the term. The latter should come as no surprise, as the concept is heavily contested by different and opposing "stakeholders", who try to appropriate it and give it a meaning according to their own interests. Some talk about the "highjacking" of sustainability (Parr 2009) and environmentalism (Welford 1997) by the corporations and capitalist states, which have more or less succeeded in blocking the advancement of environmentalism and redefining the concept of sustainable development by compromising the initial more radical elements of the discourse and placing them under their own liberal-productivist agenda. Critics of the dominant sustainable development discourse note that the initial radicalism of the environmentalist movement of the 1970s has vanished and as the UN documents on sustainable development fail to identify the historical and structural roots of environmental and social degradation, the proposed solutions cannot be transformative enough (Kothari et al. 2015).

Of particular importance to the passive revolution aspects that are discussed herewith, is the framing of the mainstream sustainable development discourse in a way that can be described as a "post-political" depoliticization of a political issue par excellence (Swyngedouw 2010, 2013). This post-political or postdemocratic (Mouffe 2005; Crouch 2004) depoliticization comes at the expense of the democratic-agonistic and inherently conflictual political terrain over the content and direction of society, economy and the planet, as the contested issues and public affairs are dealt with in a techno-managerial manner, by a consensual policy-making 
process, at the exclusion of genuine public participation ${ }^{7}$ and directed towards a one-dimensional, undisputed, predetermined end.

This, of course, does not mean that resistance to dominant policies is not taking place. There are currently more than 3,400 "ecological distribution conflicts" (Martinez-Alier and O'Connor 1996) registered at the EJAtlas (www.ejatlas.org). The environmental movement may be "the most comprehensive and influential movement of our time" (Castells 1997: 67), representing for the 'post-industrial' age what the workers' movement was for the industrial period (Temper et al. 2018). As the latter article notes, "an ecological distribution conflict can be defined as a collective action (such as a writing of petitions, demonstrations, blockades etc.), induced by existing or anticipated environmental pollution or damage to nature affecting communities, which has been caused or will be caused by increases or changes in the social metabolism."

Hence, although it is to a large extent recognized that economic growth does not by itself eliminate poverty nor does it improve the environment, the question remains why then is economic growth - at least in the Global North - still a goal of sustainable development? Obviously, to stop prioritizing growth and to start focusing seriously on reducing inequalities on the economic and ecological front, within and among countries, through redistributive policies, while downscaling the biophysical size of the economy, could have dire consequences to the process of capital accumulation and the capitalist economy as a whole. So, an alternative, passive revolution path, along the lines of a green social-democratic discourse of difference, is to reverse the question and ask if the implementation of social and environmental policies that aim to eliminate poverty and inequalities, protect the environment and tackle climate change, could in return lead to economic growth, albeit this time more inclusive and sustainable.

\section{The limits of sustainable development: green growth and the decoupling question}

It could be argued, retrospectively, that the new era of economic - yet sustainable and inclusive - growth that the Brundtland Commission asked for (WCED 1987), finds its place in the Green Economy/Green Growth/Green New Deal agenda, which has been promoted, especially after the global financial crisis of 2008, by major international organizations, such as the UNEP (2011), OECD (2011, 2017) and World Bank (2012), the supranational European Union (European Commission 2019), by countries such as Norway and Germany, and political parties like UK Labour, the German and European Greens or Bernie Sanders' and Ocasio-Cortez' wing of the US Democratic Party. There are some variations in the concept definitions and policy objectives provided by the various institutions (Jacobs 2013; Hickel and Kallis 2020), with the UNEP being perhaps the most environmentally friendly, but let's focus on the concrete case of the ambitious agenda of the European Green Deal (EGD), which is defined as "a new growth strategy that aims to transform the EU into a fair and prosperous society, with a modern, resource-efficient and competitive economy where there are no net emissions of greenhouse gases in 2050 and where economic growth is decoupled from resource use" (European Commission 2019: 2). As stated in the same Communication, the EGD is a roadmap for making the EU's economy sustainable, and this will happen by turning climate and environmental challenges into opportunities across all policy areas and making the transition just and inclusive for all.

On the above definition of the EGD, and taking into consideration the whole framing of the project by the EU institutions, policy initiatives, implementation acts and public debate, two points can be made with regard to the arguments advanced here. First, the EGD is explicitly a growth strategy. And it comes after the Eurozone debt crisis, which was accompanied by political and legitimation crisis of the EU institutions, especially in countries of the southern European periphery, along with the global environmental crisis of our time. It is, therefore, an attempt to exit a multidimensional and multi-scalar crisis, by offering a long-term

\footnotetext{
${ }^{7}$ Although the deliberative and open consultation practices to decision- and law-making processes that were introduced in the 1990s, initially posed a challenge to the established institutions and models of democracy, they soon became assimilated by the same institutions and practices (Dryzek 2000). Any recognition of the community's empowerment potentials entailed in these participatory processes cannot ignore the role played by the same processes in legitimizing the dominant discourse, institutional mechanisms and power relations.
} 
solution (Jessop 2012) ${ }^{8}$, as the immediate, fire-fighting measures that were introduced to contain the financial crisis had an adverse effect on the livelihoods of the subaltern and "middle classes", as well as to the advancement of ecological concerns. The EGD may well be seen as a new hegemonic vision and state project that can accommodate concerns of social inclusion and environmental protection. The use of the word "Deal" may imply some kind of a romantic return of Franklin D. Roosevelt's Keynesian economic policies, where the creation of new jobs will go hand in hand with the greening of the economy and the protection of the environment, and in fact, as the Green New Deal proposal in the US demonstrates, progressive forces are supportive of and may initiate such projects. However, although neo-Keynesian approaches have gained in popularity after the widespread criticism of the overly neoliberal-austerity programs of the previous period, neoliberalism is so deeply embedded in institutions, ideologies and practices, that a substantive change of this hegemonic paradigm is not easy to foresee.

Of course, a thorough analysis of the EGD as it evolves will have to cover the many fields on which it will have an impact (economy, politics, law, environment, mode of living), taking into due consideration the balance of power of the social forces involved and their consensual or opposing stances, discourses or alternative formulated projects. As a starting point, I consider van Apeldoorn's (2002) "embedded neoliberalism" account of the European model of capitalism to hold true: a (potentially) hegemonic articulation predominantly neoliberal, with elements of alternative neo-mercantilist and social-democratic ideological discourses, that has come about as an outcome of the balance of power between three transnational social forces. These are the more globalized sections of capital (including financial capital), industrial capital with deep roots and interests in the continent that may need protection against its competitors, and the labor movement and social-democratic parties, that have to a large extent shaped the institutions and practices of the Fordist European welfare state.

The second point refers to the relationship between sustainable development and 'green growth.' Dale et al. (2016) claim that as the discourse and project of sustainable development gradually lost its way, it is now refolded into the much more market-oriented green growth discourse and project, that deviates considerably from the original sustainability concerns, as it asserts that environmental sustainability is not only compatible but also depends on the market system. And Brand (2012: 28) argues that as the concept of sustainable development ("a political strategy of global environment and resource management, of ecological modernization and - at least at the beginning - an attempt to reconcile environmental problems with those of development") "has failed because of the absence of relevant socio-economic actors needed to significantly push this strategy", the concept of the 'green economy' might be in a better position to deliver. This is because it has become attractive to relevant socio-economic actors (industries in the renewable energy sector, electric vehicles and microelectronics, financial capital that finds new investment opportunities in environmental protection, agriculture, soil and infrastructure). This is especially true after the conditions created by the world financial crisis, where over-accumulated capital is seeking new investment opportunities.

It is true that the green growth project seems promising for certain sectors of capital. And it can certainly attract significant political support, form broader economic, social and political coalitions, rearrange to a certain extent power relations and lead to new accumulation regimes and modes of regulation. However, Sustainable Development (as in the 2030 Agenda) and green growth are not in conflict. ${ }^{9}$ The European Commission EGD Communication explicitly states that:

\footnotetext{
${ }^{8}$ Jessop (2012) comments that the "green new deal" can be seen in some ways as an imaginative extension of the 1990s "knowledge-based economy" imaginary, with its emphasis on competitiveness, creative and flexible attitudes in enterprise culture, and lifelong learning. The alleged dynamism of the knowledge-based economy as a mode of growth came as a response to the crisis of Atlantic Fordism and it was sidelined but not negated by the rise of a finance-dominated accumulation strategy, that reflected the interests of financial rather than industrial capital.

${ }^{9}$ The same conclusion is reached by Wanner (2015), who disagrees with the view that sustainable development is replaced by the green economy/growth discourse, and supports instead that "the green economy/growth discourse is a critical extension to the sustainable development discourse which is ultimately about the sustainability (or 'sustainable development') of neoliberal capitalism."
} 
...the Green Deal is an integral part of this Commission's strategy to implement the United Nation's 2030 Agenda and the sustainable development goals, and the other priorities announced in President von der Leyen's political guidelines. As part of the Green Deal, the Commission will refocus the European Semester process of macroeconomic coordination to integrate the United Nations' sustainable development goals, to put sustainability and the well-being of citizens at the centre of economic policy, and the sustainable development goals at the heart of the EU's policymaking and action. (European Commission 2019: 3)

Von der Leyen's political guidelines for the European Commission 2019-2024 includes the implementation of SDGs and other sustainable development thematic priorities, and the President of the Commission, in her mission letters to the Commissioners asks each one of them to ensure the delivery of the UN SDGs within their policy area, whereas the College of Commissioners as a whole will be responsible for the overall implementation of the Goals. In her mission letter to Commissioner and Executive Vice-President for the European Green Deal, Frans Timmermans, she states that "the European Green Deal should become Europe's hallmark" and "at the heart of it is our commitment to becoming the world's first climate-neutral continent" (Von der Leyen 2019: 4).

The political will and commitment on the part of the Commission and all the EU institutions for no net emissions of greenhouse gases and for a decoupling of economic growth from resource use (or "dematerialization" of the economy) has unanimously support. Improving global resource efficiency in consumption and production and endeavoring to decouple economic growth from environmental degradation is also a policy objective of the Global 2030 Agenda for Sustainable Development (SDG 8.4). But can these noble goals be achieved by the dominant sustainable development/green growth policy responses to climate change and environmental degradation?

The question of decoupling economic growth measured in GDP, from growth in environmental impacts strikes at the heart of the matter and constitutes the ultimate testing field for the theoretical assumptions and empirical evidence of those who promote the growth solution to all problems. If decoupling via scientific and technological advancements and "natural capital" substitution by "human-made capital" were feasible, then growth would be a legitimate sustainability goal. If not, other ways for decoupling should urgently be found if climate change and pressing environmental (and societal) problems are to be taken seriously.

Based on the second law of thermodynamics but also the findings of authoritative scientific studies on historical trends and model-based projections for the future, the answer to the decoupling question appears to be negative. Parrique et al. (2019), having reviewed all the empirical decoupling literature, demonstrate that absolute, global, permanent, and sufficiently fast and large decoupling of environmental pressures (both resources and impacts) from economic growth is just not taking place, and is not likely to do so successfully in the future. A concise yet thorough literature review by Hickel and Kallis (2020: 1) on the two primary dimensions of decoupling - resource use and carbon emissions - concludes that:

(1) there is no empirical evidence that absolute decoupling from resource use can be achieved on a global scale against a background of continued economic growth, and (2) absolute decoupling from carbon emissions is highly unlikely to be achieved at a rate rapid enough to prevent global warming over $1.5^{\circ} \mathrm{C}$ or $2^{\circ} \mathrm{C}$, even after optimistic policy conditions.

Ward et al., after listing four reasons why the apparent decoupling of GDP from specific resources is an illusion (resource substitution, financialization of some components of GDP, exporting of environmental impacts, rise in GDP that is not followed by a concomitant rise in material and energy throughput due to income inequality), point out that "decoupling of GDP growth from resource use, whether relative or absolute, is at best only temporary, as permanent decoupling (absolute or relative) is impossible for essential, non-substitutable resources because the efficiency gains are ultimately governed by physical limits." (Ward et al. 2016: 10). The same study concludes that "growth in GDP ultimately cannot plausibly be decoupled from growth in material 
and energy use, demonstrating categorically that GDP growth cannot be sustained indefinitely. It is therefore misleading to develop growth-oriented policy around the expectation that decoupling is possible" (p. 10). ${ }^{10}$

If this is the case, then why insist on the same old one-sided policy direction? An answer that can be given is that green growth, the "ultimate stage" of sustainable development, has just now started to warm up the engines or, better yet, set sail, and it should be given time to show the desired results. The two-fold reply to this would be, that time is pressing, if not running out, as scientists are stressing, concerning the state of the environment and the planet, and second, empirical data do not, after all, verify the theoretical premises of the growth paradigm. Of course, that would lead to a new round of debate between the optimists who see a functioning of the Kuznets' inverted U shape curve ${ }^{11}$ and those who question it, on environmental (Dale et al. 2016), social (Picketty 2013), or econometric (Stern 2017) grounds. So, instead of delving more into questions of "hard science", the focus could better be placed on the political dimension. It appears that as the would-be hegemonic discourse and project of sustainable development/green growth will try to deliver, this will entail a great deal of political, social and economic mobilization, state transformation, forming of alliances and absorbing demands - that may initially contradict the interests of dominant classes and groups - in an assimilative way that will not pose any serious threats to the "power bloc" (composed of several politically dominant classes or fractions: Poulantzas 1978). Although the power bloc enjoys the structural (or strategic) selectivity of the capitalist state (Poulantzas 1980; Jessop 1999), there are new opportunities and challenges for all the players involved, but, again, the time factor is crucial nowadays. Failure to deliver on the promised expectations will lead to a legitimation crisis and will threaten not only the "sustainable development historic bloc" (Igoe et al. 2010), but even the survival of the planet itself in the age of Anthropocene.

\section{Degrowth's radical critique}

The sustainable development discourse may have many aspects that contribute to environmental and social welfare but it is basically a top-down reform project that aims at correcting the environmental and social externalities to economic growth. It is run by governments that abide by the logic of capital ${ }^{12}$ and although in principle it promotes civic and stakeholder engagement, public participation is limited and is done in a way that does not seriously challenge the dominant economic paradigm. On the contrary, the emerging (yet still marginal) alternative, multi-disciplinary, degrowth academic paradigm (Martinez-Alier et al. 2010; Weiss and Cattaneo 2017; Kallis et al. 2018), has evolved, in a consistent and quite influential way since the first decade of this century, from an activist movement and it retains close contacts and open communication with social movements that support a degrowth transition in economy and society (Demaria et al. 2013). In fact, many of the sustainability concepts of political ecology have already been introduced from grassroots environmental justice organizations since the early 1980s (Martinez-Alier et al. 2014), and an explicit goal of degrowth is the repoliticization of environmentalism and ending of the depoliticizing consensus on sustainable development (Asara et al. 2015). Degrowth challenges the very foundations of "actually existing" capitalism and erstwhile socialism alike, as it postulates that infinite economic growth in a finite planet is just impossible and must be undesirable (at least for those aspects of growth that do not directly satisfy societal needs). If we accept the premise that capitalism is not sustainable in the long run without the dynamics of capital accumulation and economic growth (periods of economic crisis, which are accompanied by crises in political and ideological fields, are a proof of that), then degrowth has a strong anti-capitalist/anti-consumerist orientation. This is in

\footnotetext{
${ }^{10} \mathrm{Cf}$. Wiedmann et al.'s study on the material footprint of nations (2013).

${ }^{11}$ Economic growth may initially lead to deterioration in the environment (and an increase of inequality), but after a point (say, when per capita income reaches a range of US\$5,000 to US\$8,000, Dasgupta et al. 2002), the situation becomes better as regards environmental degradation (and social inequality).

12 In no way does this imply a capital- or class-reductionist account of the state. The capitalist state is not automatically following the logic of capital and is not the mere instrument of the ruling class. The same way "capital is not a thing but a social relation between persons, established by the instrumentality of things" (Marx 1990(1867), Capital vol. 1, chapter 33) so the state is a "material condensation of a relationship of forces" (Poulantzas 1980). Following the Gramscian political science tradition, a "strategic-relational approach" (Jessop 2009) can offer compelling insights into the workings of the capitalist state and politics.
} 
stark contrast to the sustainable development project and theoretically makes any assimilative attempt by the dominant or hegemonic discourses, social forces and institutions quite challenging.

The 'degrowth' concept and program is made up of a variety of interrelated theories, disciplines and political proposals. ${ }^{13}$ The critique of growth coming from environmental economists, ecological economists and political ecologists, comes down to the conclusion that we have as societies lived for so long accepting the myth of continued growth, but it failed us. Notable contributions include Nicholas Georgescu Roegen's (1971) pioneer thermodynamic analysis of the economy, Meadows et al.'s (1972) famous "limits to growth" forecasting study, Herman Daly's (1991) systematic exposition of the issues and call for a steady-state economy, Andre Gorz's New Left political ecology (1980), Serge Latouche's (2009) critique of economism, Tim Jackson's (2009) comprehensive account of prosperity without growth, Peter Victor's (2008/2019) case for managing by design without growth, and the Research and Degrowth group at the Autonomous University of Barcelona (D'Alisa, Demaria and Kallis 2015).

Degrowth has been defined as a voluntary, democratically negotiated, equitable downscaling of economic production and consumption to assure that society's throughput - resource use and waste - stays within safe ecosystem boundaries (Kallis 2011; Schneider et al. 2010). As Daly (2007: 17) argues, the rich countries of the planet have reached a stage of "non-economic growth" (increases in production come at the cost of resource depletion and well-being that is worth more than the commodities made) and the population is facing a "futility limit." This means any utility (level of satisfaction of the populations' needs and wants) earned from increased production and consumption is surpassed by the disutility of the level of sacrifice that has to be endured (workload, loss of leisure, resource depletion, exposure to pollution, congestion). ${ }^{14}$ This is why a degrowth transition is needed towards a "steady-state economy", i.e. a "non-growing" economy, where material throughput (extraction of raw materials from nature and their return to nature as waste) is retained within the regenerative and assimilative capacities of the ecosystem (Farley 2015; Daly 1991), and where, in neoclassical economic terms, marginal costs will equal marginal benefits. Daly's argument is that as we move from the traditional "empty world" to today's "full world" economy, we must adjust the economics accordingly (2007: 13, 79, 159). We can no longer afford to treat the environmental issues as "externalities." If in the old times human made capital (e.g. fishing boats) was limited, today the remaining natural capital (fish) is limited, and, hence, the policy implication is that we must start economizing on and invest in the limiting factor (natural capital).

The critique of the abstract neoclassical economic model that neglected the material, biophysical aspect of economy, and the recognition that the economy is, in fact, a subsystem of - and totally depended on - the broader finite ecosystem, which acts both as a source of low-entropy and a sink for high-entropy matter-energy (Georgescu-Roegen 1971), is credited on the work of Daly and the ecological economists. The degrowthers, of course, share this approach, but their more original contribution has to do with their political, anti-utilitarian stance. The critique of growth is (or should) not been done solely on the basis of just reducing throughput and societal metabolism or "preserving life" and the planet. That would entail a neutral, non-political, utilitarian way of looking at things, whereas a political contribution would call for a political and collective construction of the meaning of life (Romano 2015). The degrowthers are aware of this, as is evident in their stress on autonomy - defined as the ability of a collective to decide its own future in common, freed from heteronomous imperatives and givens, such as religion or the laws of the economy (Castoriadis 1987; Kallis et al. 2015) from wage-labor (Gorz 1982) and large technocratic and centralized bureaucratic institutions (Illich 1973). They adhere to the tenets of Buddhist economics and the "small is beautiful" slogan (Schumacher 1973), Gandhian economics and the "economy of permanence" (Kumarappa 1958), or the low-impact "spaceship economy" in contradistinction to the voracious "cowboy economy" (Boulding 1966). They stand critical of growth, GDP, commodification and relations of inequality between countries of the Global North and Global South (Dorninger et al. 2021). They are supportive of alternative constructions of economy and society, such

\footnotetext{
${ }^{13}$ I use a rather broad definition of degrowth that includes theoretical trends critical of growth such as the steady-state economy and post-growth.

${ }^{14}$ Degrowthers often refer to the Easterlin (1974) paradox that happiness over time does not depend on rising GDP per capita. See Buchs and Koch (2019) on the debate about wellbeing.
} 
as producer-consumer cooperatives, eco-communities, local currencies and social philosophies of Buen Vivir and Ubuntu, and promote concrete welfare reform policies such as work-sharing and the reduction of working hours, job guarantee schemes, introduction of income guarantee, basic and maximum income/wealth, and a shifting from a corporate to a cooperative economy (Kallis 2011, 2015; Kallis et al. 2012; Daly 2008; D'Alisa et al. 2015; Kothari et al. 2019; Booth 1995).

Even if some degrowthers are not explicitly anti-capitalists, their critique, directly or indirectly, challenges the dominant capitalist paradigm in two fundamental ways - political and economic. On the political level, it attacks the long-standing doctrine of orthodox political economy and the established political parties of the right and left alike, that you have to first "grow the pie" so that there's enough income and wealth for everyone afterwards. If escaping the issue of just redistribution via the growth imaginary is no longer possible, then a more genuine political settlement of social questions becomes imminent. On the economic level, you don't have to be a Marxist to recognize that capitalism cannot exist without constantly revolutionizing the productive forces, expanding markets and consuming ever-growing resources and energy. Halting economic growth will seriously damage the dynamics of capitalism; or not?

\section{The limits of degrowth: steady state economy or eco-socialism?}

Aside from the fundamental objection to the steady state economy (SSE) coming from neoclassical economists who see growth as the only way for societies to develop and prosper, Marxist ecologists, sociologists and economists (Magdoff and Foster 2011; Foster et al. 2010; Kovel 2007; Foster 2002; O'Connor 1998) are making the claim that quantitative growth is an inherent characteristic of the capitalist reproduction process and, since growth, by default, puts enormous pressure on nature, capitalism is not at the end of the day ecologically sustainable. Smith (2010) argues that the "grow or die" survival maxim is a built-in feature of capitalism for at least three reasons:

1. The division of labor raises productivity and output, compelling producers to find more markets for their growing output;

2. Competition compels producers to seek to expand their market share, in order to defend their position against competitors;

3. The modern corporate form of ownership is under constant pressure from the owners and shareholders to grow.

On the other hand, proponents of SSE, such as Daly (2008, 2010) and Lawn (2011), believe that a steadystate economy is compatible with capitalism (a system based on private property and markets), albeit regulated by a strongly interventionist social-democratic state. After all, as Lawn (2011) rightly points out, the real deal in capitalism is to make a profit, not to grow the company. If you don't make a profit you die and even though profit is made by increasing output and sales (the first option), the profitability can also be accomplished by producing better quality products and selling the same quantity of output at a higher price (a second option) or by producing the same quantity more efficiently (the third option). It is thus possible to have a steady-state capitalist economy, with profits but not necessarily with an increased throughput (growth).

Blauwhof (2012) discusses these issues thoroughly. He notes that although Lawn's first option obviously leads to growth in both throughput and GDP, the third option does not. In fact, it can lead to a decreased demand, unsold products and a lower GDP. However, this option has limits, as wages, working hours per product and other input costs cannot be squeezed forever and also, at some point, the competition will catch up with the efficiency improvements. Regarding the second option, this could lead to GDP growth but not throughput growth, as increased revenues can be earned by using the same amount of inputs. Nevertheless, the relation of higher prices with constant wages (with which the goods will be bought) can lead to a series of problems associated with a lack of demand. In other words, although in principle the profit motive is not identical to the growth imperative, a zero-growth economy does not make much sense to the profit-maximizing players of a competitive economy. 
By using Marxian economic analysis of capital accumulation (Blauwhof 2012), ${ }^{15}$ including aspects of

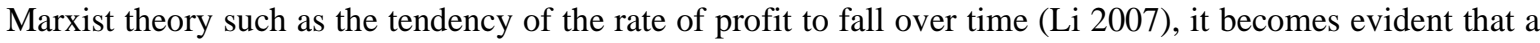
zero-growth society cannot be compatible with an economic system based on the pursuit of profit and accumulation. Even more important is to look at the geography of the spatial expansion of capital to overcome the limits of capital accumulation, as "capitalism could not survive without being geographically expansionary and perpetually seeking out 'spatial fixes' for its problems" (Harvey 2001: 25). For Marxist eco-socialists, a fundamental contradiction exists between capital accumulation and planetary boundaries. Capital as a process (or social relation) of self-expanding value, bound by the laws of capitalist competition, runs the risk of annihilating itself, and the whole planet as a matter of fact, since there seem to be environmental (Meadows 2004; Turner 2014) and social (Hirsch 1977) limits to growth. Accordingly, the SSE institutional and policy reforms proposed by Daly (2013) and other ecological economists and degrowthers (Kallis 2011, 2015; Kallis et al. 2012), are well-intentioned and ethical but not really compatible with the workings of a capitalist economy and the state, which depends on the normal growth pattern of capital accumulation in order to perform its welfare duties (Blauwhof 2012). Degrowth reforms, if not addressed to relevant socio-economic and political actors, run the risk of remaining largely voluntaristic and apolitical.

This does not mean that the reforms should not be pursued now, or that they are futile (the welfare state might regulate and provide for the reproduction of capitalist social formations but at the same time it supports non-commodified labor practices and imposes limits to capital) ${ }^{16}$, and it does not in any way imply that they should first wait for an all-encompassing change of economic paradigm to take place (indicatively, as the ecosocialists propose, one from a system based on private property of the means of production and the commodification of all aspects of social life and nature, to one based on a collective ownership by freely associated individuals and a restoration of the commons). ${ }^{17}$ It does, however, mean that the proposed reforms which match the degrowth criteria should form a coherent political platform of demands, policies and actions that aims at a broader and substantial change of the dominant economic paradigm. It also means that for reforms to be successful, and thus to achieve ecological and social sustainability, there must be common ground and alliances with social groups that are crucial for the achievement of hegemony. Working-class organizations are one such group, and due to the potential conflict between ecological sustainability and full employment (Lawn 2009), working class people and the middle strata of the population have to be assured that any degrowth policies will not endanger their already precarious situation. Otherwise, reform proposals will stay indifferent to major social actors and hence with no real impact on politics and society. ${ }^{18}$ Alternatively, in case the usual

\footnotetext{
${ }^{15}$ Many misunderstandings begin by the way key terms are treated in different theoretical frameworks. 'Capital' in Marxist political economy is not the constant stock of human-created wealth of the mainstream or environmental economics, but a "value in motion", following the cycle of money to commodity to money plus profit ('M-C-M'). 'Capital accumulation' is the process of reconverting surplus value into capital, whereby capital can realize more value for itself, as described in Marx's "simple reproduction" and "reproduction on an extended scale" schemes in Capital Volume 1 (Marx 1990[1867] Blauwhof 2012; Harvey 2018). Pirgmaier (2017) criticizes (and she in turn has been criticized by Farley and Washington 2018) the use of neoclassical economic theory and reasoning by Daly and the SSE school, which in her opinion leads to fundamental theoretical inconsistencies and contradicts the core values and ambitions of ecological economics.

${ }^{16}$ Ian Gough (2017) outlines a three-stage transition to an alternative needs-based economy: the first is eco-efficient green growth, which requires a shift from liberal to coordinated capitalism; the second - interim - stage of recomposing consumption, would require a more "reflexive" form of capitalism (regulating advertising, cuts in consumption and more taxation of high-carbon luxury goods, preventive economic policies, including nationalization of investment, integration and empowerment of local and bottom up action); the third stage is degrowth, which is "incompatible with the accumulation drive of any form of capitalism yet is ultimately - and quite soon - essential for our future prosperity, if not our very existence" (Gough 2017: 15).

17 Mann and Wainwright (2018) examine four possible political futures that try to address climate change: "Climate Leviathan" (a capitalist global order), "Climate Behemoth" (a capitalist anti-globalist order), "Climate Mao" (a noncapitalist global order), and "Climate X" (a non-capitalist, post- sovereignty - either on a national or global scale - order). Duvernoy and Busk (2020) take issue with the two non-capitalist orientations.

${ }^{18}$ Georgescu's and Daly's contributions were basically ignored for many decades by mainstream economists, established political institutions, and the public. Compare with the powerful worldwide embrace of Marx's ideas by subaltern social forces and the fierce attack on them, or attempts at accommodation and distortion, by dominant powers of all kinds.
} 
policies and scientific fixes to environmental problems fail dramatically, they could be transformed and interpreted in a 'passive revolution' by the power bloc in an accommodating, neutralized, technical "policy making" manner. This means degrowth will have little influence on the growth imaginary in practical terms.

\section{Passive revolution: easier with sustainable development, harder but not impossible with degrowth}

From the above discussion we can conclude, first of all, that the sustainable development project is a case of passive revolution par excellence. Intense social and environmental pressures on the capitalist reproduction process and the growth paradigm have at some point to be dealt with by the transnational and national dominant powers. The initial mobilization of grassroots subaltern and environmental groups, and certainly not only from the rich countries (Martinez-Alier 2002), has been replaced by government and private sector policy making initiatives, which in turn have led to a de-radicalization of the demands for social and environmental justice and a de facto exclusion of the popular masses from a genuinely open democratic dialogue as to the way social inequalities and environmental degradation should be tackled. Primarily, a discourse of difference was used, where the "negatively-charged contradictions" were transformed into "positively differentiated contrarieties" (Jessop 2019: 13). The flip side is that the now-legitimized and at times quite advanced social and environmental demands, which are integrated in the sustainable development discourse, can, especially in times of organic crisis, expose the contradictory nature of capitalist growth and pose a threat to the dominance or hegemony of the power bloc.

In any case, the sustainable development discourse and project does not create any major logical inconsistencies with the dominant growth paradigm and can be compatible with the logic of capital accumulation. Thus, it is easier to accommodate the social and environmental concerns of sustainable development and green growth in this context. On the contrary, the degrowth discourse differs in a substantial way, as it explicitly contradicts the basic premises of the orthodox growth narrative. At the moment it remains inconceivable for any major political party around the world to embrace a comprehensive degrowth platform and to then ask for the votes of the citizenry. But as - and to the extent that - the degrowth school of thought is succeeding in advancing its research and ideas and gaining in popularity and as the climate crisis becomes ever more threatening to the planet and possibly undermines capitalist hegemony, the chances are that some elements from the degrowth toolbox will be used - in a 'passive revolution manner' - by big business and governments.

A recent article in the Harvard Business Review (Roulet and Bothello 2020) sets the tone, as it explains "why degrowth shouldn't scare business" and suggests strategies for firms such as pursuing degrowth-adjusted product design, engaging in value-chain repositioning, and leading through degrowth-oriented standard-setting. Governments, in times of the Covid-19 pandemic, as an attempt to protect the health of the population, have adopted extraordinary measures that have inflicted major setbacks to economic growth, resulting in unprecedented rates of recession, but also - as a side effect - in significant carbon emissions reductions.

Of course, a humanitarian crisis accompanied by involuntary business-cycle contraction and job cuts is not degrowth. Degrowth is, according to the open letter of more than 1,000 experts from 60 countries who call for degrowth as a post-Covid-19 path (The open letter working group 2020)

...a democratically planned yet adaptive, sustainable, and equitable downscaling of the economy, leading to a future where we can live better with less. This requires transforming the current profit-oriented capitalist system. It opposes blind faith in market forces and dismisses a pursuit of 'green growth' and decoupling as main strategies to solve environmental and social problems.

Interestingly enough, the degrowth school of thought, by becoming a politically conscious movement, seems to be earning a wider acceptance. 
The same letter "urges national and international institutions as well as civil society and economic actors to follow five principles in their efforts to counter the current societal and economic crisis, taking into account social and environmental ills":

1. Put life at the center of our economic systems,

2. Radically re-evaluate how much and what work is necessary for a good life for all,

3. Organize society around the provision of essential goods and services,

4. Democratize society, and

5. Base political and economic systems on the principle of solidarity.

These principles, as further specified in the letter and the degrowth literature in general, certainly aim at a more egalitarian and sustainable society and they do pose obstacles to the normal circuits of capital accumulation. But as long as their critical approach to the general concept of "growth society" is not combined with a class analysis and critique of capitalism (Foster 2011), degrowth's arguments can be picked up in an ad hoc manner and transformed by "bourgeois forces" so that they don't become detrimental to the basic mode of operation of capitalist social formations. For example, degrowth tries to answer the problem of growth and/or unemployment by suggesting shorter working hours and work-sharing combined with income guarantees. The implementation of all these combined measures on a large scale infringes on the accumulation regime and the state budget, but in reality, as many countries are already pursuing such policies, and what we are witnessing is a response to the decrease in demand, that may satisfy some minimum living standards of the working class. This stands nowhere near the magnitude of a full-blown eco-socialist strategy, which would call for giving all people work (a fundamental human need and right), albeit in a creative, non-alienated, "use-value", and sustainable fashion.

The policies exercised by national states all over the world that aim to combat Covid-19 19 are illuminating. In effect, a degrowth exercise of major magnitude is already taking place (but not in the sense we are discussing it here), and this has led to workplace closures, working-hour losses and decreases of labor income (ILO 2020), not to mention the creation of a new landscape in industrial relations, with the intrusion of teleworking and other practices that will diminish labor rights even further, as well as the bargaining power of the working class. Furthermore, as governments are quite generous in throwing money in the economy at present, a new wave of austerity measures could emerge later, due to the rise of public debt. The ironic thing is that the legitimating principle for the austerity policies is sustainability (intergenerational justice) itself: release future generations from the heavy burden of debt. And, frankly, periods of economic contraction work generally well for the state of the environment. In other words, there is ample room for maneuver for the dominant or hegemonic forces to exercise alternative accumulation strategies and project renewed hegemonic visions, in which they can use their version of degrowth (similarly to their version of "socialism for the rich and capitalism for the poor", that has to do with privatizing profits and socializing losses), and continue their business as usual with accumulating capital and ruling the nation.

Degrowth is obliged to offer viable solutions to the job losses and declining living standards of working people and the poor (Pollin 2018: 22). This can be done only when it takes seriously the class and class-relevant dimension of the economic and ecological crisis, as the latter is not just a problem that "humanity" faces with respect to the degradation of nature (Fotopoulos 2007). In fact (and in theory), only in periods of economic growth has the position of the working classes seen some improvement. After all, "the growth economy is not just the outcome of domination of specific imaginary significations or values, but the outcome of social struggle on the one hand and technological (including organizational) and socio-economic developments on the other" (Fotopoulos 2007). The degrowth school tends to avoid the central social question of capitalism and prefers to draw attention to alternative paths of economic and social organization, such as the social and solidarity economy, and sustainable community movement organizations (Forno and Weiner 2020). It places emphasis on creative, bottom-up initiatives and horizontal networks of collectivities that are blossoming rhizomatically (Deleuze and Guattari 1987). It supports a co-evolution of social, cultural and ecological systems (Norgaard

${ }^{19}$ Another "illth" symptom [(Daly 2011) of capitalist economic growth. See Wallace et al. (2020); Chuang (2020). 
1994; Kallis and Norgaard 2010). These are all welcome features of another way of doing things now (Carlsson and Manning 2010; Gibson-Graham 2006; Demaria et al. 2019) but they are not enough, since any good examples of an alternative economy work only on the fringes of the dominant capitalist mode of production.

In societies based on class antagonisms and unequal distribution of power, any scientific evidence and logically valid arguments offered by the degrowth movement and its supporters, are a necessary but not sufficient condition for social change. ${ }^{20} \mathrm{~A}$ collective identity that is willing to initiate change is needed. This is constructed through the mechanisms of hegemony (Gramsci 1971; Laclau and Mouffe 1985), that is by articulating a plurality of seemingly autonomous and unconnected interests and demands into a coherent hegemonic vision that is collectively forged through discourse and aims at spreading its influence into society and "capturing"/altering the state, in order to bring forth social change. ${ }^{21}$ In addition, and not so much in juxtaposition (Stavrakakis 2014), due account should be given to the critique of vertical-hierarchical relations of power embedded in the hegemonic practices of organization and representation, and the support of posthegemonic horizontal-networked forms of political agency that characterize modern grassroots social movements (Kioupkiolis 2014).

It is not very difficult to form a social base for a degrowth agenda that promotes policies such as resource caps, carbon and green taxes, progressive income taxes, a basic and a maximum income/wealth, income guarantees, job guarantees, and working hour/workweek reductions. The programs of green, social-democratic and left-wing parties already include some of these proposals, and the Covid-19 global lockdown has showed that prioritizing human health and safety over purely economic criteria can take place through concerted action. Again, a painful non-voluntary temporary pause of economic growth, is not what constitutes a proper de-growth approach, nonetheless it has had some positive impacts on the environment (Tollefson 2020) and society (Love 2020) which did have not gone unnoticed. More radical policy proposals that aim at drastic income and wealth redistribution reforms, in parallel with the promotion of producer cooperatives, as an alternative democratic form of organization of the economy, would require the formation of a well-built alliance between environmental and working-class movements.

It is imperative that such an alliance be formed for another, very fundamental reason. Passive revolution is not only about a reformist strategy and a discourse of difference, but also right-wing populism and the use of a discourse of equivalence. Ecology (or science) is not a privileged field for the Left. Right-wing populist forces can certainly develop an authoritarian and reactionary ecological discourse themselves. They have done this in the past and they are attempting it now (Biehl and Staudenmaier 2011; Phellan 2018; Manavis 2018; Sparrow 2019).

Leading figures in the degrowth movement have recently attempted to address the relationship of policy and social change with the role of the state directly (D'Alisa and Kallis 2020), via Eric Olin Wright's (2009) analysis of ruptural, interstisial and symbiotic visions of systemic transformations. They have concluded that a Gramscian theory of the state suits degrowth's work on the combination of grassroots and institutional actions. Koch (2020: 115) also argues that state-led "eco-social" policies, influenced by materialist state and sustainable welfare theories and integrated in a comprehensive policy strategy, "have the potential to overcome the growth imperative in the economy and policymaking and break the growth-related glass ceiling of the environmental state." Other theorists don't agree that real change can ever occur through the state, but at the same time

\footnotetext{
${ }^{20}$ Even though scientific evidence seems to be disproving the decoupling hypothesis, the de- or post-growth proponents, and the environmental movement in general for that matter, should not put all their money on science. Philippe Mirowski (2013: 334; Mirowski et al. 2013) argues that, as science on a neo-liberal planet is wrested from the domain of public good and is increasingly conforming to market imperatives, the old self-assuring belief of the Left that it has science on its side, no longer holds (if it ever did). The neo-liberal response to global warming needs to be challenged. It starts from the shortterm - a "buying-time" political version of "climate denialism", continues with medium-term "carbon permit trading" (which, in the concrete case of the EU Emissions Trading System, fails to meet its goals), and "ends" up with the long-term science-fiction "geoengineering" vision, aiming at large-scale manipulations of the Earth's climate (space mirrors that would deflect sunlight, carbon sequestration techniques such as ocean seeding, burying biochar and using genetically modified plants and trees, or weather modification such as cloud seeding).

${ }^{21}$ Absolutely crucial in this politico-historical process is the role of feeling - passion and sentimental connection, as Gramsci stresses (1971: 418).
} 
acknowledge that changing the world without taking power is very difficult (Holloway 2019: viii). In any case, for those who seek radical social change, any cracks in the system should be exploited to open alternative, positive spaces (Holloway 2010). Next to the autonomous work of grassroots organizations, there is sufficient scope for action in trying to introduce degrowth proposals in mainstream policy settings. From basic and maximum income on the national scale (Alexander 2015) to specific changes on the global SDGs agenda (Hickel 2019).

Some proposals, those that will not have a major adverse effect on the interests of national or transnational power blocs, could be transformed or neutralized and integrated in state projects. As the passive revolution modus operandi requires, the state will try to exclude genuine mass political participation from agenda-setting and decision-making processes, and leave power relations intact. This should not be a reason for progressive alternative forces to give up promoting their goals. From the global (SDGs and post 2030 sustainability agenda) and regional level (EGD) to the national and local, they should intervene and try to introduce as many degrowth aspects as possible into official policy contexts. That would require - but also contribute to - the empowerment of degrowth, both as an academic paradigm and a social movement, so that, along with other social, political and environmental movements with which it should form strategic alliances, it can help create a new collective will, based on intellectual and moral reform and the attainment of ecosocialist (or steady-state?) hegemony in civil and political society. This is an immense task indeed.

\section{Conclusion}

The environmental and social dimensions of capitalist economic growth have been dealt with for many decades now by the policies of "sustainable development." These policies have not managed to seriously slow climate change or environmental degradation, nor rising socio-economic inequalities, because they do not deviate from the logic of the dominant economic paradigm. The latter is challenged by the emergent degrowth approach, which proposes an alternative organization of the economy and society. At present degrowth is considered radical or utopian, and hence of no use in official policymaking. However, there is now a multifaceted crisis, accelerated by the global response to the Covid-19 pandemic, and a new growth mode that seems to be taking shape, as with the European Green Deal.

This means some items from the degrowth agenda might find a sympathetic ear from dominant political and social forces. Degrowth's critique need not be dismissed outright, and its policy proposals could be integrated into new hegemonic visions and state projects, provided that they don't damage the workings of any new accumulation strategies. This is a transitional period, and analysis (via perhaps the methods of the régulation school) of a "post-post-Fordist" accumulation regime and mode of regulation that will include some degrowth aspects is still speculative. In this article I have limited myself to a (Gramscian) politico-historical discussion of sustainability, focusing on the limits of sustainable development and the strengths and weaknesses of degrowth, hinting of the possible dangers of co-optation. As I have shown, these can be avoided.

\section{References}

Alexander, S. 2015. Basic and maximum income. In G. D'Alisa, F. Demaria and G. Kallis (eds.). Degrowth: a vocabulary for a new era. London: Routledge. Pp. 146-148.

Asara, V., I. Otero, F. Demaria and E. Corbera. 2015. Socially sustainable degrowth as a social-ecological transformation: repoliticizing sustainability. Sustainability Science 10: 375-384.

Biehl, J. and Staudenmaier, P. 2011. Ecofascism revisited: lessons from the German experience. Porsgrunn: New Compass Press.

Blauwhof, F.B. 2012. Overcoming accumulation: is capitalist steady-state economy possible? Ecological Economics 84: 254-261.

Booth, D. 1995. Economic democracy as an environmental measure. Ecological Economics 12(3): $225-236$.

Boulding, K. 1966. The economics of the coming Spaceship Earth. In Jarrett, H. (ed.). Environmental quality in a growing economy: essays from the Sixth RFF Forum, Baltimore: Johns Hopkins University Press.

Boyer, R. and Y. Saillard. 2002. Régulation theory: the state of the art. London: Routledge. 
Brand, U. 2012. Green economy - the next oxymoron? No lessons learned from failures of implementing sustainable development. Gaia - Ecological Perspectives for Science and Society 21(1): 28-32.

Buchs, M. and M. Koch. 2019. Challenges for the degrowth transition: the debate about wellbeing. Futures 105: 155-165.

Carlsson, C. and F. Manning. 2010. Nowtopia: strategic exodus? Antipode 42(4): 924-953.

Castells, M. 1997. The information age, 3 vols. Oxford: Blackwell.

Castoriadis, C. 1987. The imaginary institution of society. Cambridge: Polity Press.

Chuang. 2020. Social contagion: microbiological class war in China. http://chuangcn.org/2020/02/socialcontagion/ (accessed 17 Oct. 2020).

Crouch, C. 2004. Post-democracy. Cambridge: Polity Press.

Crutzen, P. and E. Stoermer. 2000. The "Anthropocene." International Geosphere-Biosphere Programme (IGBP) Newsletter 41.

Dale, G., M. Mathai and J. Puppim de Oliveira. 2016. green growth, political economy and the alternatives. London: Zed.

D'Alisa, G., F. Demaria and G. Kallis (eds.). Degrowth: a vocabulary for a new era. London: Routledge.

D'Alisa, G. and G. Kallis. 2020. Degrowth and the state. Ecological Economics 169: 106486.

Daly, H. 1991. Steady-state economics. Second Edition with New Essays, Washington: Island Press.

Daly, H. 2007. Ecological economics and sustainable development. Northhampton, MA: Edward Elgar.

Daly, H. 2008. Towards a steady-state economy. London: Sustainable Development Commission.

Daly, H. 2010. The operative word here is 'somehow.' Real-World Economics Review 54: 103.

Daly, H. 2011. Wealth, Illth, and Net Welfare. Center for the Advancement of the Steady State Economy. https://steadystate.org/wealth-illth-and-net-welfare/. (accessed 16 Oct. 2020)

Daly, H. 2013. Top 10 policies for a steady state economy. Center for the Advancement of the Steady State Economy. https://steadystate.org/top-10-policies-for-a-steady-state-economy/ (accessed 16 Oct. 2020).

Dasgupta, S., B. Laplante, H. Wang, and D. Wheeler. 2002. Confronting the environmental Kuznets Curve. Journal of Economic Perspectives 16(1): 147-168.

Davies, J. 2018. The birth of the Anthropocene. Berkeley: University of California Press.

Davies, H. and Z. Todd. 2017. On the importance of a date, or decolonizing the Anthropocene. ACME An International Journal of Critical Geographies 16(4): 761-780.

Deleuze, G. and F. Guattari. 1987. A thousand plateaus. Minneapolis: University of Minnesota Press.

Demaria, F., F. Schneider, F. Sekulova and J. Martinez-Alier. 2013. From an activist slogan to a social movement. Environmental Values 22(2): 191-215.

Demaria, F., G. Kallis and K. Bakker. 2019. Geographies of degrowth: Nowtopias, resurgences, and the decolonization of imaginaries and places. Environment and Planning E: Nature and Space 2(3): 431-450.

Dobson, A. (ed.). 1999. Fairness and futurity: essays on environmental sustainability and social justice. Oxford: Oxford University Press.

Dorminger, C., A. Hornborg, D.J. Abson, H. von Wehrden, A. Schaffartzik, S. Giljum, J.-O. Engler, R.L. Feller, K. Hubacek and H. Wieland. 2021. Global patterns of ecologically unequal exchange: implications for sustainability in the $21^{\text {st }}$ century. Ecological Economics 179: 106824.

Dryzek, J. 2000. Deliberative democracy and beyond: liberals, critics, contestations. Oxford: Oxford University Press.

Duvernoy, R. and L.A. Busk. 2020. Climate X or Climate Jacobin? A critical exchange on our planetary future. Radical Philosophy Review 23(2): 175-200.

Easterlin, R.A. 1974. Does economic growth improve the human lot? Some empirical evidence. In P. David and M. Reder (eds.). Nations and households in economic growth: essays in honor of Moses Abramovitz (pp.89-125). New York: Academic Press. 
European Commission 2019. The European Green Deal. COM(2019) 640 final. Brussels: European Commission.

Farley, J. 2015. Steady state economics. In G. D'Alisa, F. Demaria and G. Kallis (eds.). Degrowth: a vocabulary for a new era. London: Routledge. Pp. 49-52.

Farley, J. and H. Washington. 2018. A response to 'The neoclassical Trojan horse of steady-state economics' by Pirgmaier. Ecological Economics 147: 442-449.

Forno, F. and R. Weiner (eds.). 2020. Sustainable community movement organizations: solidarity economies and rhizomatic practices. London: Routledge.

Foster, J.B. 2002. Ecology against capitalism. New York: Monthly Review Press.

Foster, J.B. 2011. Capitalism and degrowth. an impossibility theorem. Monthly Review 62(8).

Foster, J.B., B. Clark and R. York. 2010. The ecological rift: capitalism's war on the Earth. New York: Monthly Review Press.

Fotopoulos, T. 2007. Is degrowth compatible with a market economy? The International Journal of Inclusive Democracy 3(1).

Gibson-Graham, J.K. 2006. A postcapitalist politics. Minneapolis: University of Minnesota Press.

Georgescu-Roegen, N. 1971. The entropy law and the economic process. Cambridge, MA: Harvard University Press.

Gorz, A. 1980. Ecology as politics. Montreal: Black Rose Books.

Gorz, A. 1982. Farewell to the Working Class: an essay on post-industrial socialism. London: Pluto.

Gough, I. 2017. Heat, greed and human need: climate change, capitalism and sustainable wellbeing. Cheltenham: Edward Elgar.

Gramsci, A. 1971. Selections from the Prison Notebooks. Edited and translated by Quentin Hoare and Geoffrey Nowell Smith. London: Lawrence \& Wishart.

Haraway, D. 2015. Anthropocene, Capitalocene, Plantationocene, Chthulucene: making kin. Environmental Humanities 6(1): 159-165.

Harvey, D. 2001. Globalization and the "spatial fix". Geographische Revue 2001/2.

Harvey, D. 2018. A companion to Marx's Capital: the complete edition. London: Verso.

Hickel, J. 2019. The contradiction of the Sustainable Development Goals: growth versus ecology on a finite planet. Sustainable Development 27: 873-884.

Hickel, J. and G. Kallis. 2020. Is green growth possible? New Political Economy 25(4): 469-486.

Hirsh, F. 1977. Social limits to growth. London: Routledge.

Holloway, J. 2019. Change the world without taking power: the meaning of revolution today. London: Pluto.

Holloway, J. 2010. Crack capitalism. London: Pluto.

Igoe, J., K. Neves and D. Brockington. 2010. A spectacular eco-tour around the historic bloc: theorising the convergence of biodiversity conservation and capitalist expansion. Antipode 42(3): 486-512.

Illich, I. 1973. Tools for conviviality. New York: Harper \& Row.

International Labour Organization (ILO). 2020. ILO Monitor: COVID-19 and the world of work. Sixth edition Updated estimates and analysis, 23 September 2020. ILO. (accessed 17 Jan. 2020)

Jackson, T. 2009. Prosperity without growth? The transition to a sustainable economy. London: Sustainable Development Commission.

Jacobs, M. 1999. Sustainable Development as a contested concept. In A. Dobson (ed.). Fairness and futurity: essays on environmental sustainability and social justice. Oxford: Oxford University Press. Pp. 21-45.

Jacobs, M. 2013. Green growth. In R. Falkner (ed.). The handbook of global climate and environmental policy. Oxford: Wiley-Blackwell.

Jessop, B. 1983. Accumulation strategies, state forms, and hegemonic projects. Kapitalistate 10: 89-111. 
Jessop, B. 1999. The strategic selectivity of the state: reflections on a theme by Poulantzas. Journal of Hellenic Diaspora 25(1-2): 41-77.

Jessop, B. 2009. A strategic-relational approach: an interview with Bob Jessop. BobJessop.org (accessed 14 Oct. 2020).

Jessop, B. 2012. Economic and ecological crises: green new deals and no-growth economies. Development 55(1): $17-24$.

Jessop, B. 2016. The state: past, present, future. Cambridge: Polity Press.

Jessop, B. 2019. Critical discourse analysis in Laclau and Mouffe's post-Marxism. Simbiótica 6(2): 8-30.

Kallis, G. 2011. In defence of degrowth. Ecological Economics 70(5): 873-880.

Kallis, G. 2015. Yes, we can prosper without growth: 10 policy proposals for the New Left. 23 January. ThisChangesEverything.org (accessed 15 March 2021).

Kallis, G. and R.B. Norgaard. 2010. Coevolutionary ecological economics. Ecological Economics 69(4): 690699.

Kallis, G., C. Kerschner and J. Martinez-Alier. 2012. The economics of degrowth. Ecological Economics 84: 172-180.

Kallis, G., F. Demaria and G. D'Alisa. 2015. Degrowth. In G. D'Alisa, F. Demaria and G. Kallis (eds.). Degrowth: a vocabulary for a new era. London: Routledge. Pp. 1-18.

Kallis, G., V. Kostakis, S. Lange, B. Muraca, S. Paulson and M. Schmelzer. 2018. Research on degrowth. Annual Review of Environment and Resources 43: 291-316.

Kioupkiolis, A. 2014. A hegemony of the multitude: muddling the lines. In Kioupkiolis A. and G. Katsambekis (eds.). Radical democracy and collective movements today: the biopolitics of the multitude versus the hegemony of the people (pp. 149-168). Farnham: Ashgate. Pp. 149-168.

Koch, M. 2020. The state in the transformation to a sustainable postgrowth economy. Environmental Politics 29(1): 115-133.

Kovel, J. 2007. The enemy of nature: the end of capitalism or the end of the world? London: Zed.

Kothari, A., F. Demaria and A. Acosta. 2015. Sustainable development is failing but there are alternatives to capitalism. The Guardian, 21 July._(accessed 20 Oct. 2020).

Kothari, A., A. Salleh, A. Escobar, F. Demaria and A. Acosta (eds.). 2019. Pluriverse: a post-development dictionary. New Delhi: Tulika Books.

Kumarappa, J. C. 1958. Economy of permanence: a quest for a social order based on non-violence. Wardha (India): Sarva Seva Sangh.

Laclau, E. 1977. Politics and ideology in Marxist theory: capitalism - fascism - populism. London: NLB.

Laclau, E. 2005. On populist reason. London: Verso.

Laclau, E. 2006. Why constructing a people is the main task of radical politics. Critical Inquiry 32(4): 646-680.

Laclau, E. and C. Mouffe. 1985. Hegemony and socialist strategy. London: Verso.

Latouche, S. 2009. Farewell to growth. Cambridge: Polity Press.

Lawn, P. 2009. The potential conflict between ecological sustainability and full employment. In Lawn, P. (ed.) Environment and employment. a reconciliation. London: Routledge. Pp. 24-93.

Lawn, P. 2011. Is steady-state capitalism viable? A review of the issues and an answer in the affirmative. In R. Costanza, K. Limburg and I. Kubiszewski (eds.). Ecological Economics Reviews. Annals of the New York Academy of Sciences. 1219: 1-25.

Love, S. 2020. COVID-19 broke the economy: what if we don't fix it? Vice 16 June 2020 (accessed 19 Oct. 2020).

Lélé, S. 1991. Sustainable Development: a critical review. World Development 19(6): 607-621.

Li, M. 2007. Capitalism with zero profit rate? Limits to growth and the law of the tendency of the rate of profit to fall. Department of Economics Working Paper Series. University of Utah. (accessed 15 Oct. 2020) 
Magdoff, F. and J.B. Foster. 2011. What every environmentalist needs to know about capitalism: a citizen's guide to capitalism and the environment. New York: Monthly Review Press.

Manavis, S. 2018. Eco-fascism: the ideology marrying environmentalism and white supremacy thriving online. New Statesman 21 September. (accessed 20 Oct. 2020)

Mann, G. and Wainwright, J. 2018. Climate Leviathan: a political theory of our planetary future. London: Verso.

Martinez-Alier, J., 2002. The environmentalism of the poor: a study of ecological conflicts and valuation. Cheltenham: Edward Elgar.

Martinez-Alier, J. and M. O'Connor. 1996. Ecological and economic distribution conflicts. In R. Costanza, J. Martinez-Alier and O. Segura (eds.). Getting down to Earth: practical applications of ecological economics. Washington, DC: Island Press/ISEE.

Martinez-Alier, J., U. Pascual, F.D. Vivien and E. Zaccai. 2010. Sustainable de-growth: mapping the context, criticisms and future prospects of an emergent paradigm. Ecological Economics 69(9): 1741-1747.

Martinez-Alier J., I. Anguelovski. P. Bond, D. Del Bene, F. Demaria, J. Gerber, L. Greyl, W. Haas, H. Healy, V. Marín-Burgos, G. Ojo, M. Porto, L. Rijnhout, B. Rodríguez-Labajos, J. Spangenberg, L. Temper, R. Warlenius and I. Yánez. 2014. Between activism and science: grassroots concepts for sustainability coined by Environmental Justice Organizations. Journal of Political Ecology 21(1): 19-60.

Marx, K. 1990(1867). Capital: a critique of political economy. Volume I. Trans. Ben Fowkes. London: Penguin Classics.

Meadows, D.H. 2004. The limits to growth: the 30-year update. White River Junction, VT: Chelsea Green.

Meadows, D.H., D.L. Meadows, J. Randers and W.W. Behrens III. 1972. The limits to growth. New York: Universe Books.

Mirowski, P. 2013. Never let a serious crisis go to waste: how neoliberalism survived the financial meltdown. London: Verso.

Mirowski, P., J. Walker and A. Abboud. 2013. Beyond denial. Overland 210.

Moore, J. (ed.). 2016. Anthropocene or Capitalocene? Nature, history, and the crisis of capitalism. Oakland: PM Press.

Mouffe, C. 2005. On the political. London: Routledge.

Norgaard, R. 1994. Development betrayed: the end of progress and a coevolutionary revisioning of the future. London: Routledge.

Nussbaum, M. 2011. Creating capabilities: the human development approach. Cambridge, MA: The Belknap Press of Harvard University Press.

O'Connor, J. 1998. Natural causes: essays in ecological Marxism. New York: Guilford.

Organisation for Economic Cooperation and Development (OECD) 2011. Towards Green Growth. Paris: OECD.

Organisation for Economic Cooperation and Development (OECD) 2017. Green Growth Indicators 2017. Paris: OECD.

Parr, A. 2009. Hijacking sustainability. Cambridge, MA: MIT Press.

Parrique, T. et al. 2019. Decoupling debunked: evidence and arguments against green growth as a sole strategy for sustainability. Brussels: European Environmental Bureau.

Paulson, S. 2017. Degrowth: culture, power and change. Journal of Political Ecology 24(1): 425-448.

Picketty, T. 2014. Capital in the twenty-first century. Cambridge, MA: Harvard University Press.

Pirgmaier, E. 2017. The neoclassical Trojan horse of steady-state economics. Ecological Economics 133: 5261.

Phelan, M. 2018. The menace of eco-fascism. The New York Review 22 October. (accessed 20 Oct. 2020)

Pollin, R. 2018. De-growth vs a Green New Deal. New Left Review 112: 5-25.

Poulantzas, N. 1978. Political power and social classes. London: Verso. 
Poulantzas, N. 1980. State, power, socialism. London: Verso.

Reid, D. 1995. Sustainable development: an introductory guide. London: Earthscan.

Romano, O. 2015. Anti-utilitarianism. In D'Alisa, G., Demaria, F. and G. Kallis (eds.). Degrowth: a vocabulary for a new era. London: Routledge. Pp. 21-24.

Roulet, T. and J. Bothello. 2020. Why "de-growth" shouldn't scare business. Harvard Business Review. February 14. (accessed 17 Oct. 2020)

Sachs, W. 1999. Planet dialectics: explorations in environment and development. London: Zed.

Sassoon, A. 1987. Gramsci's politics. London: Hutchinson.

Sassoon, A. 2000. Gramsci and contemporary politics: beyond pessimism of the intellect. London: Routledge.

Schmelzer, M. 2016. The hegemony of growth: the OECD and the making of the economic growth paradigm. Cambridge: Cambridge University Press.

Schneider, F., G. Kallis and J. Martinez-Alier. 2010. Crisis or opportunity? Economic degrowth for social equity and ecological sustainability. Introduction to this special issue. Journal of Cleaner Production 18: 511-518.

Schumacher, E.F. 1973. Small is beautiful: a study of economics as if people mattered. London: Blond \& Briggs.

Sen, A. 1999. Development as freedom, New York: Alfred Knopf.

Smith, R. 2010. Beyond growth or beyond capitalism? Real-World Economics Review 53: 28-42.

Sparrow, J. 2019. Eco-fascists and the ugly fight for 'our way of life' as the environment disintegrates. The Guardian 29 November. (accessed 20 Oct. 2020)

Springett, D. and M. Redclift. 2015. Sustainable Development: history and evolution of the concept. In M. Redclift and D. Springett (eds.). Routledge International Handbook of Sustainable Development. London: Routledge. Pp. 3-28.

Stavrakakis, Y. 2014. Hegemony or post-hegemony? Discourse, representation and the revenge(s) of the real. In Kioupkiolis A. and G. Katsambekis (eds.). Radical democracy and collective movements today. Farnham: Ashgate. Pp. 111-132.

Stern, D. 2017. The environmental Kuznets curve after 25 years. Journal of Bioeconomics 19: 7-28.

Sum, N.L. and B. Jessop. 2013. Towards a cultural political economy: putting culture in its place in political economy. Cheltenham: Edward Elgar.

Swyngedouw, E. 2010. Apocalypse forever? Post-political populism and the spectre of climate change. Theory, Culture and Society 27(2-3): 313-232.

Swyngedouw, E. 2013. The non-political politics of climate change. ACME: An International Journal for Critical Geographies 12(1): 1-8.

Temper, L., F. Demaria, A. Scheidel, D. Del Bene, J. Martinez-Alier. 2018. The Global Environmental Justice Atlas: ecological distribution conflicts as forces for sustainability. Sustainability Science 13: 573-584.

Tollefson, J. 2020. How the coronavirus pandemic slashed carbon emissions -in five graphs. Nature 582(7811).

Turner, G. 2014. Is global collapse imminent? An updated comparison of the Limits to Growth with Historical Data. Research Paper Series No. 4. Melbourne Sustainable Society Institute.

The Open Letter Working Group. 2020. https://www.degrowth.info/en/2020/05/more-than-1000-experts-callfor-degrowth-as-post-covid-19-path/ (accessed 17 Oct. 2020).

United Nations Department of Economic and Social Affairs (UNDESA) 2020. World Social Report 2020. Inequality in a rapidly changing world. New York: UNDESA.

United Nations Development Programme (UNDP) 2019. Human Development Report 2019: beyond income, beyond averages, beyond today: inequalities in human development in the $21^{\text {st }}$ century. New York: UNDP.

United Nations Development Programme (UNDP) 1990. Human Development Report 1990: concept and measurement of human development. New York: UNDP. 
United Nations Environment Programme (UNEP) 2011. Towards a green economy: pathways to sustainable development and poverty eradication - a synthesis for policy makers. Nairobi: UNEP.

UN General Assembly Resolution 2015. Transforming our world: the 2030 Agenda for Sustainable Development. A/RES/70/1 (25 September).

Van Apeldoorn, B. 2002. Transnational capitalism and the struggle over European integration. London: Routledge.

Victor, P. 2019. Managing without growth: slower by design, not disaster ( $2^{\text {nd }}$ edition). Northampton, MA: Edward Elgar.

Von der Leyen, U. 2019. Mission letter to Frans Timmermans, Executive Vice-President for the European Green Deal. Brussels, 1 Dec. 2019.

Wallace, R., A. Liebman, A., L.F. Chaves and R. Wallace. 2020. COVID-19 and circuits of capital. Monthly Review 72(1).

Wanner, T. 2015. The new 'passive revolution' of the green economy and growth discourse: maintaining the 'sustainable development" of neoliberal capitalism. New Political Economy 20(1): 21-41.

Ward, J.D., P.C. Sutton, A.D. Werner, R. Costanza, S.H. Mohr and C.T. Simmons. 2016. Is decoupling GDP growth from environmental impact possible? PLoS ONE 11(10): e0164733.

WCED (World Commission on Environment and Development) 1987. Our Common Future. UN-Oxford University Press.

Weiss, M. and C. Cattaneo. 2017. Degrowth - taking stock and reviewing an emerging academic paradigm. Ecological Economics 137: 220-230.

Welford, R. 1997. Hijacking environmentalism: corporate responses to sustainable development. London: Earthscan.

Wiedmann, T.O., H. Schandl, M. Lenzen, D. Moran, S. Suh, J. West and K. Kanemoto. 2013. The material footprint of nations. Proceedings of the National Academy of Sciences 112(20): 6271-6276.

World Bank. 2012. Inclusive green growth: the pathway to sustainable development. Washington, DC: World Bank.

Wright, E.O. 2009. Envisioning real utopias. London: Verso. 